\title{
STRATEGI PEMBELAJARAN MEMBACA DAN MENULIS PERMULAAN MELALUI MEDIA KATA BERGAMBAR
}

\author{
Rahmawati \\ Program Studi Teknik Informatika, Universitas Indraprasta PGRI \\ Email: rhmarisma10@gmail.com
}

\begin{abstract}
Abstrak
Tujuan penelitian ini adalah mengembangkan Media Kata Bergambar (MKB) untuk meningkatkan kualitas pembelajaran membaca dan menulis permulaan di kelas 1 SD. Adapun tujuan khusus penelitian ini adalah menguji coba prototipe Media Kata Bergambar dan mengembangkan model Media Kata Bergambar. Prosedur pengembangan Media Kata Bergambar ini didasarkan pada langkah-langkah pengembangan Research and Development (R\&D) Model. Data tersebut dapat diketahui dengan menggunakan dua jenis instrumen, yaitu pedoman wawancara dan pedoman observasi. Penelitian ini menghasilkan produk Media Kata Bergambar yang memiliki karakteristik dan spesifikasi yang tampak dari (1) wujud, (2) ukuran, (3) bentuk tulisan, (4) gambar, (5) jenis kata yang dipakai, dan (6) warna Media Kata Bergambar.
\end{abstract}

Kata kunci: Membaca, Menulis, Media kata bergambar

\begin{abstract}
The purpose of this research is to develop an Illustrated Word Medium (MKB) in a bid to improve the quality of early reading and writing activities in the 1st grade. Further, the specific purpose of this research is to test and to develop the prototypes of Illustrated Word Medium. The procedures for the development of this Illustrated Word Medium model are established based on the development steps of Research and Development $(R \& D)$ model. The data of the research are generated by using two types of instrument, namely interview and observation guidelines. This research then creates an Illustrated Word Medium product which has the characteristics and specifications that can be seen from (1) form, (2) size,(3) style of writing, (4) picture, (5) type ofthe words used and (6) color of Illustrated Word Medium.
\end{abstract}

Keywords: Reading, Writing, Illustrated Word Medium

\section{Pendahuluan}

Membaca merupakan salah satu jenis kemampuan berbahasa tulis yang bersifat reseptif karena dengan membaca, seseorang akan memperoleh informasi, memperoleh ilmu pengetahuan serta pengalaman-pengalaman yang bersifat baru. Semua yang diperoleh melalui bacaan akan memungkinkan seseorang mampu mempertinggi pemikiran dan wawasannya dan memperluas pandangannya, karena membaca adalah jendela dunia. Membaca juga merupakan hal yang tidak terpisahkan dari kehidupan sehari-hari. Kegiatan membaca setiap saat dilakukan oleh individu. Di era global banyak informasi-informasi disampaikan melalui media-media elektronik maupun media cetak, dengan demikian kemampuan membaca merupakan kemampuan dasar yang penting yang harus dimiliki oleh individu. Oleh karena itu, pembelajaran membaca di sekolah mempunyai peranan yang sangat penting.

Usia siswa kelas 1 Sekolah Dasar berkisar antara 6-7 tahun. Di mana pada usia ini, anak mulai diajarkan membaca secara formal. Pada usia 6-7 tahun inilah siswa mulai dapat belajar membaca dengan baik, karena siswa telah memiliki kematangan dalam berpikir dan memiliki kesiapan membaca yang lebih baik dibandingkan dengan anak yang berusia 4-5 tahun. Pembelajaran membaca di kelas rendah merupakan pembelajaran membaca tahap awal, kemampuan membaca yang diperoleh di kelas rendah terutama di kelas 1 sekolah dasar akan menjadi dasar pembelajaran membaca di kelas-kelas berikutnya dan membaca di 
jenjang tersebut akrab dikenal sebagai membaca permulaan. Membaca permulaan adalah salah satu aspek keterampilan bahasa yang diperuntukkan bagi siswa kelas awal. Permulaan membaca hanya berlangsung dua tahun, yaitu kelas 1 dan kelas 2 sekolah dasar. Bagi siswa kelas 1 dan kelas 2 tersebut, membaca merupakan kegiatan belajar mengenal bahasa tulis.

Melalui tulisan itulah siswa dituntut untuk dapat memahami dan menyuarakan lambanglambang bunyi bahasa tersebut. Namun, pengucapan kata secara tepat hanya akan tercapai jika pengenalan bunyi itu dapat membangkitkan makna sebagaimana halnya dalam penggunaan bahasa lisan. Selain itu, latar belakang pengalaman siswa juga akan mempengaruhi. Siswa yang memiliki banyak pengalaman akan lebih mudah dalam mengembangkan pemahaman kosakata dan konsep yang didapatkannya dalam teks bacaan.

Pada tahap membaca permulaan siswa mulai diperkenalkan dengan berbagai simbol huruf, mulai dari simbol huruf /a/ sampai dengan /z/. Ada 4 kelompok karakteristik siswa yang kurang mampu membaca permulaan, yaitu dilihat dari: (1) kebiasaan membaca, (2) kekeliruan mengenal kata, (3) kekeliruan pemahaman, dan (4) gejala-gejala lainnya yang beraneka ragam. Siswa yang sulit membaca, sering memperlihatkan kebiasaan dan tingkah laku yang tidak wajar. Gejala-gejala gerakannya penuh ketegangan seperti: (1) mengernyitkan kening, (2) gelisah, (3) irama suara meninggi, (4) menggigit bibir, dan (5) adanya perasaan tidak aman yang ditandai dengan perilaku menolak untuk membaca, menangis, atau mencoba melawan guru. Gejala-gejala tersebut muncul akibat dari kesulitan siswa dalam membaca. Indikator kesulitan siswa dalam membaca permulaan, antara lain: (1) siswa tidak mengenali huruf, (2) siswa sulit membedakan huruf, (3) siswa kurang yakin dengan huruf yang dibacanya itu benar, dan (4) siswa tidak mengetahui makna kata atau kalimat yang dibacanya.

Pemahaman dalam membaca permulaan, di sisi lain hanya menuntut siswa untuk mampu melafalkan lambang-lambang bunyi dan memahami makna bacaan secara sederhana. Pusat perhatian membaca permulaan adalah membantu siswa untuk belajar membaca. Maka pembelajaran membaca permulaan di kelas 1, siswa lebih banyak dituntut untuk melafalkan lambang bunyi bahasa tulis daripada untuk memahami dan menafsirkan isi bacaan.

Pembelajaran membaca permulaan di sekolah dasar bertujuan agar siswa mengenal dan menguasai sistem tulisan sehingga mereka dapat membaca dengan menggunakan sistem tersebut. Siswa sekolah dasar harus mampu membaca dengan tepat. Ketepatan membaca permulaan sangat dipengaruhi oleh keaktifan dan kreativitas guru yang mengajar di kelas I sekolah dasar. Keberhasilan belajar siswa dalam mengikuti proses kegiatan belajar mengajar ditentukan oleh penguasaan kemampuan membaca mereka. Banyak pakar pendidikan mencari solusi bagaimana cara memperbaiki pembelajaran kemampuan membaca permulaan. Belajar membaca permulaan sebaiknya dilakukan melalui gambar-gambar dengan kata-kata sederhana.

Pendidikan memegang peranan penting dalam pembangunan. Dengan pendidikan dipersiapkan tenaga-tenaga dalam pembangunan bangsa dan negara. Pendidikan yang terpadu dan terus-menerus dapat mengembangkan seluruh potensi yang ada dalam diri seseorang. Peningkatan mutu pendidikan, khususnya pada tingkat sekolah dasar telah menjadi kebijaksanaan pemerintah yang harus diwujudkan dengan sebaik-baiknya. Usaha ini dilaksanakan dalam rangka peningkatan kualitas sumber daya untuk mencapai tujuan pembangunan. Dalam usaha peningkatan mutu faktor guru memegang peran penting, karena itu profesionalisme tenaga guru kelas digalang secara sistematis, melalui wadah-wadah pembinaan professional guru. 
Maju mundurnya masyarakat dalam suatu negara bergantung pada maju mundurnya pendidikan di Negara tersebut. Mutu pendidikan itu dapat dicapai dengan baik apabila proses belajar-mengajar diselenggarakan dalam kelas atau sekolah benar-benar efektif dan fungsional sesuai dengan sasaran yang diinginkan. Membaca dan menulis permulaan merupakan kemampuan awal yang harus dimiliki anak untuk dapat membuka cakrawala pengetahuan yang lebih luas. Untuk itu, kemampuan membaca dan menulis permulaan harus dipupuk sejak dini. Jika membaca merupakan kemampuan berbahasa tulis yang bersifat reseptif, maka menulis merupakan kemampuan menghasilkan tulisan.

Namun, berdasarkan survei terhadap media kata bergambar yang digunakan di sekolahsekolah maupun yang dipasarkan di toko-toko buku serta yang beredar di masyarakat luas, diperoleh fakta bahwa belum ada satupun media kata bergambar yang mengakomodasi berbagai prinsip dari berbagai bidang ilmu dan teori yang terkait dalam pembuatan media pembelajaran yang sesuai dipakai sebagai media pembelajaran membaca dan menulis permulaan untuk anak kelas $1 \mathrm{SD}$.

Untuk itu, upaya pengembangan media yang menarik dan sesuai untuk pembelajaran membaca dan menulis permulaan di kelas 1 SD (tahap awal membaca dan menulis) berupa media kata bergambar perlu dilakukan, dengan merujuk pada prinsip-prinsip perkembangan membaca dan menulis pada anak. Namun, karena jenis media kartu kata bergambar merupakan bentuk media yang dikembangkan berdasarkan metode Struktur Analisis Sintesis (SAS), maka penelitian ini hanya difokuskan pada mengujicoba prototipe media yang berbentuk modifikasi dari bentuk media yang pernah digunakan di SD maupun yang ada di toko-toko buku serta mengembangkannya menjadi produk media dengan mengadopsi berbagai teori dan prinsip-prinsip pembelajaran yang dikemukakan oleh para ahli pendidikan, ahli psikologi perkembangan anak, maupun ahli media.

Penelitian ini diharapkan dapat memberikan manfaat terhadap pengembangan ilmu pengetahuan, teknologi, dan seni, yakni:

Secara teoritis dapat memberikan manfaat:

1. Menyusun prototipe Media Kata Bergambar untuk pembelajaran Membaca dan Menulis Permulaan di kelas 1 SD.

2. Mendukung aplikasi teoritis tentang pengaruh penggunaan media gambar terhadap kemampuan Membaca dan Menulis Permulan.

Secara praktis, juga dapat memberikan manfaat:

1. Bagi dunia pendidikan, hasil penelitian ini dapat dimanfaatkan oleh para guru untuk memilih dan menentukan jenis media yang dapat membantu pembelajaran Membaca dan Menulis Permulaan serta untuk menyediakan media belajar anak yang mudah digunakan, menarik, dan sesuai dengan perkembangan anak dalam rangka merangsang kegemaran membaca.

2. Bagi dunia industri, hasil penelitian ini dapat dimanfaatkan untuk memproduksi Media Kata Bergambar untuk dipasarkan di sekolah-sekolah maupun toko buku.

Berdasarkan permasalahan yang ingin diteliti dalam penelitian ini, maka tujuan penelitian ini adalah:

1. Menyusun prototipe Media Kata Bergambar untuk pembelajaran Membaca dan Menulis Permulaan di kelas 1 Sekolah Dasar.

2. Mendeskripsikan hasil uji coba prototipe Media Kata Bergambar untuk pembelajaran Membaca dan Menulis Permulaan di kelas 1 Sekolah Dasar.

3. Mengembangkan produk model Media Kata Bergambar untuk pembelajaran Membaca dan Menulis Permulaan di kelas 1 Sekolah Dasar. 


\section{Tinjauan Pustaka}

Menurut Zuchdi dan Budiasih (2001a: 50), membaca merupakan proses memperoleh makna dari barang cetak. Selanjutnya dikatakan bahwa ada dua cara yang ditempuh pembaca dalam memperoleh makna cetak, yaitu (1) langsung, yakni menghubungkan ciri penanda visual dari tulisan dengan maknanya, dan (2) tidak langsung, yakni mengidentifikasi bunyi dalam kata dan menghubungkannya dengan makna. Cara pertama digunakan oleh pembaca lanjut dan cara kedua digunakan oleh pembaca permulaan. Membaca permulaan merupakan kemampuan membaca pada tahap keberwacanaan. Secara teknis, pada tahap keberwacanaan ini, anak-anak diharapkan dapat menemukan sendiri sistem kebahasaan bahasa Indonesia melalui proses pembelajaran bahasa yang dilakukan berdasarkan konteks.

Tahap keberwacanaan ini merupakan tujuan pembelajaran di Sekolah Dasar kelas-kelas awal, yaitu kelas 1 dan 2. Combs (1996: 15) memilah kegiatan membaca permulaan menjadi 3 tahap, yaitu tahap persiapan, tahap perkembangan, dan tahap transisi. Dalam tahap persiapan, anak mulai menyadari tentang fungsi barang cetak, konsep tentang cara kerja barang cetak, konsep tentang huruf, dan konsep tentang kata. Anak usia dini berada dalam tahap pertumbuhan dan perkembangan yang paling pesat, baik fisik maupun mental (Suyanto, 2005: 5). Maka tepatlah bila dikatakan bahwa usia dini adalah usia emas (golden age), di mana anak sangat berpotensi mempelajari banyak hal dengan cepat.

Konsep perkembangan dirumuskan oleh H. Werner (dalam Gunarsa, 2008: 15) dengan mengemukakan bahwa perkembangan merupakan suatu proses yang mula-mula global, masif, belum terpecah atau terperinci kemudian semakin lama semakin banyak, berdiferensiasi, dan terjadi integrasi yang hirarkis. Penggunaan istilah masa awal anak-anak (early childhood) menyebutnya usia prasekolah ketika anak masuk sekolah untuk persiapan masuk ke sekolah formal yaitu SD. Pada masa itu anak perlu mendapatkan selain pengetahuan juga keterampilan dan budi pekerti untuk dapat menyesuaikan diri pada kehidupan dewasa. Umumnya orang Indonesia menggolongkan masa awal anak itu pada usia 7-12 tahun (Sekolah Dasar kelas 1-6).

Menurut Hurlock (2006: 97), proses tumbuh kembang kemampuan gerak seorang anak disebut perkembangan motorik. Secara umum perkembangan ini dibagi dua yaitu perkembangan motorik kasar dan motorik halus. Keterampilan ini pada dasarnya berkembang sejalan dengan kematangan saraf dan otot. Dalam tahap perkembangan, anak mulai memahami pola bahasa yang terdapat dalam barang cetak. Anak mulai belajar memasangkan satu kata dengan kata lain. Dalam tahap transisi, anak mulai mengubah kebiasaan membaca bersuara menjadi membaca dalam hati. Anak mulai dapat melakukan kegiatan membaca dengan santai.

Namun, menurut Wrigth, etc (2006: 138-143), mengajar anak untuk dapat membaca dan menulis merupakan kegiatan yang sulit dilakukan. Apalagi untuk mengajar Membaca dan Menulis Pemulaan pada anak-anak usia kelas awal yang masih berada dalam usia bermain dan belum memungkinkan untuk menghadapkan mereka pada situasi pembelajaran yang serius. Dari penelitian yang telah dilakukan terhadap pembelajaran Membaca dan Menulis Pemulaan (Nisrina, 2000: 165) telah membuktikan bahwa secara umum penguasaan membaca dan menulis permulaan siswa SD belum maksimal. Dalam hal ini Mudiono (2000a: 191) mengemukakan pendapatnya bahwa guru akan memiliki kompetensi mengajar jika paling tidak menguasai pemahaman dan penerapan secara taktik berbagai metode pembelajaran serta hubungannya dengan belajar, di samping kemampuan-kemampuan lain yang menunjang. Beberapa hasil penelitian menunjukkan rendahnya kemampuan baca tulis siswa dan banyaknya keluhan terhadap pelaksanaan kegiataembelajaran yang diduga akibat kelemahan guru. 
Terkait dengan upaya perancangan media pembelajaran yang dibuat oleh guru, dalam hasil penelitian Mudiono (2000b: 193-194) terhadap kemampuan guru dalam pembelajaran membaca dan menulis permulaan menunjukkan rendahnya kemampuan guru dalam merencanakan dan menentukan metode serta memilih dan menetapkan media di Sekolah Dasar. Selain itu, hasil penelitian yang dilakukan Mudiono (2000c: 194) menunjukkan bahwa guru sangat kurang kemampuannya dalam menentukan, memilih, dan menggunakan media sesuai dengan tujuan. Untuk mengatasi masalah tersebut, perlu dilakukan perancangan pembelajaran yang mempertimbangan segi kemenarikan penyajiannya.

Menurut Degeng (2003: 2) perancangan pembelajaran dapat dijadikan titik awal perbaikan kualitas desain pembelajaran. Untuk itu, pengembangan media yang tepat merupakan suatu usaha untuk menyiapkan kondisi belajar yang lebih baik yang pada akhirnya dapat meningkatkan mutu pembelajaran membaca permulaan di Sekolah Dasar. Salah satu bentuk upaya pengembangan media yang dipakai dalam pembelajaran membaca permulaan di Sekolah Dasar berdasarkan pendekatan Struktural Analisis Sintesis (SAS) adalah media kartu kata bergambar.

Media berasal dari bahasa latin yaitu jamak dari kata medium yang secara harfiah berarti perantara atau pengantar. Media adalah perantara atau pengantar pesan dari pengirim ke penerima pesan (Arief, 2002a: 6). Secara umum media pembelajaran dalam pendidikan disebut media, yaitu berbagai jenis komponen dalam lingkungan siswa yang dapat merangsangnya untuk berpikir, menurut Gagne (dalam Arief, 2002b: 6). Sedangkan menurut Brigs (dalam Arief, 2002c: 6) media adalah segala alat fisik yang dapat menyajikan pesan serta merangsang siswa untuk belajar.

Jadi, media merupakan segala sesuatu yang dapat digunakan untuk menyalurkan pesan dari pengirim dan penerima sehingga dapat merangsang pikiran, perasaan, minat dan perhatian sedemikian rupa sehingga proses belajar terjadi (Arief, 2002d: 6). Adapun menurut Heinich, dkk (2002: 9) menyatakan bahwa media berasal dari bahasa latin, merupakan bentuk jamak dari kata "Medium" yang secara harfiah berarti "Perantara" (between), yaitu perantara sumber pesan (source) dengan penerima pesan (receiver). Dalam proses pembelajaran, media ini dapat diartikan sebagai berikut:

1. Teknologi pembawa pesan yang dapat dimanfaatkan untuk keperluan pembelajaran (Schramm, 1977).

2. Sarana fisik untuk menyampaikan isi/materi pembelajaran seperti buku, film, video, slide, dan sebagainya (Briggs, 1977).

3. Sarana komunikasi dalam bentuk cetak maupun pandang dengar, termasuk teknologi perangkat kerasnya (NEA, 1969).

Menurut Latuheru (dalam Hamdani, 2005: 10) menyatakan bahwa media pembelajaran adalah bahan, alat atau teknik yang digunakan dalam kegiatan belajar mengajar dengan maksud agar proses interaksi komunikasi edukasi antara guru dan siswa dapat berlangsung secara tepat guna dan berdaya guna.

Berdasarkan pengertian-pengertian yang telah diberikan, maka media pembelajaran merupakan segala sesuatu yang digunakan dalam kegiatan pembelajaran agar dapat merangsang pikiran, perasaan, minat dan perhatian siswa sehingga proses interaksi komunikasi edukasi antara guru (atau pembuat media) dan siswa dapat berlangsung secara tepat guna dan berdaya guna. Media yang digunakan dalam proses pembelajaran harus dapat memotivasi siswa untuk giat dalam belajar. Sesuatu dapat dikatakan sebagai media apabila media tersebut digunakan dalam menyampaikan atau menyalurkan pesan dengan tujuantujuan pendidikan dan pembelajaran. 


\section{Metodologi Penelitian}

Penelitian ini merupakan penelitian pengembangan dengan menggunakan metode penelitian dan pengembangan produk (research and development) (Borg, 2003: 572). Dipilihnya metode penelitian dan pengembangan produk ini didasari suatu pertimbangan, yakni (1) tujuan penelitian dan pengembangan produk pendidikan adalah suatu produk akhir yang dapat digunakan secara efektif di program pendidikan, (2) penelitian dan pengembangan produk dikembangkan sebagai kelanjutan potensial dari temuan dalam penelitian dasar terapan yang dilakukan di dalam sekolah menjadi sebuah produk pendidikan yang bermanfaat. Untuk itu, prosedur pengembangan Media Kata Bergambar ini didasarkan pada langkah-langkah pengembangan model penelitian dan pengembangan produk, yaitu (1) pengembangan prototipe Media Kata Bergambar untuk pembelajaran Membaca dan Menulis Permulaan di kelas 1 SD, (2) ujicoba prototipe kepada siswa kelas 1 SD dan direvisi, dan (3) produk model Media Kata Bergambar.

Data penelitian ini ada dua jenis, yakni (1) data berupa informasi yang diperoleh melalui wawancara dengan siswa kelas 1 SD mengenai Media Kata Bergambar yang diperlihatkan kepada mereka dan melalui wawancara dengan guru-guru SD, serta (2) data dari hasil observasi tentang kelayakan Media Kata Bergambar sebagai sebuah media. Data yang diperoleh dalam penelitian ini dipakai sebagai dasar pengembangan produk Media Kata Bergambar dalam pembelajaran Membaca dan Menulis Permulaan untuk siswa kelas 1 SD.

Subjek penelitian ini adalah siswa kelas 1 SDN 04 Pagi Jagakarsa. SDN 04 pagi Jagakarsa beralamat di Jalan kelapa tiga no 24. Subjek penelitian ini dijadikan sebagai sumber data untuk menganalisis kebutuhan media pembelajaran dan subjek ujicoba prototipe pengembangan media. Kelas 1 SDN 04 pagi ini beranggotakan 35 siswa yang dibina oleh seorang guru kelas yang juga merangkap sebagai wali kelas bernama Ibu Risnawati. Instrumen yang digunakan dalam penelitian ini berupa pedoman wawancara dan pedoman observasi. Pedoman wawancara digunakan untuk memperoleh informasi tentang perwujudan prototipe Media Kata Bergambar yang dipergunakan dalam pembelajaran Membaca dan Menulis Permulaan pada siswa kelas 1 SD. Pedoman observasi dipakai untuk mengobservasi pelaksanaan pembelajaran dengan menggunakan Media Kata Bergambar dan untuk mengobservasi kelayakan Media Kata Bergambar sebagai sebuah media. Prototipe Media Kata Bergambar dipergunakan untuk memberikan model bentuk Media Kata Bergambar yang akan dikembangkan menjadi media pembelajaran Membaca dan Menulis Permulaan yang diberikan untuk siswa kelas $1 \mathrm{SD}$.

Teknik pengumpulan data yang digunakan dalam penelitian ini adalah wawancara tidak terstruktur dan observasi pelaksanaan pembelajaran sebagai bentuk ujicoba prototipe Media Kata Bergambar. Wawancara digunakan untuk mewawancarai informan dalam hal ini siswa SD kelas 1 dan guru yang mengajar di kelas tersebut. Dalam pelaksanaan ujicoba, guru melakukan kegiatan pembelajaran sebagaimana biasanya. Dalam hal ini hanya guru yang tahu bahwa pembelajaran yang dilakukan ketika itu adalah pembelajaran yang berfokus pada mengujicoba prototipe Media Kata Bergambar, sedangkan siswa diupayakan tidak mengetahuinya. Peneliti hadir juga di kelas untuk melakukan observasi secara langsung terhadap pelaksanaan pembelajaran yang menggunakan Media Kata Bergambar. Namun, kehadiran peneliti diupayakan tetap menjaga iklim natural pada kelas.

Dari hasil observasi, dapat diamati kekurangan-kekurangan prototipe Media Kata Bergambar yang telah dirancang peneliti, misalnya huruf yang digunakan terlalu kecil atau warnanya tidak menarik, gambarnya terlalu kecil, gambarnya rancu, dan sebagainya. Selanjutnya hasil observasi tersebut dikroscekkan dengan hasil wawancara dengan siswa dan guru untuk ditemukan kekurangan-kekurangan prototipe MKB. Dari kekurangan-kekurangan tersebut, 
peneliti berupaya memperbaikinya dalam upaya menghasilkan produk MKB yang layak sebagai media pembelajaran.

Data yang sudah dikumpulkan dalam kegiatan pengumpulan data kemudian dianalisis dan ditafsirkan dengan menggunakan prosedur sebagai berikut: (1) menerjemahkan jenis data menjadi data kualitatif, (2) Mengidentifikasi data, yakni mengidentifikasi data yang terkumpul digunakan sebagai bahan untuk melakukan kegiatan klasifikasi, (3) mengklasifikasikan data sesuai kebutuhan pengembangan media, (4) pengembangan prototipe MKB untuk pembelajaran membaca dan menulis permulaan di kelas $1 \mathrm{SD}$, (5) analisis terhadap hasil ujicoba berupa analisis aspek fisik dan kualifikasi MKB sebagai bentuk media pembelajaran, (6) revisi terhadap prototipe MKB, dan (7) produk akhir MKB untuk pembelajaran membaca dan menulis permulaan di kelas 1 SD.

\section{Hasil dan Pembahasan}

Menurut Clay (2000: 193) ada tiga hal pokok yang perlu diperhatikan guru dalam pembelajaran Membaca dan Menulis Permulaan, yaitu (1) pengembangan aspek sosial anak, yakni kemampuan bekerja sama, percaya diri, pengendalian diri, kestabilan emosi, dan rasa tanggung jawab, (2) pengembangan fisik, yakni pengaturan gerak motorik, koordinasi gerak mata, dan (3) perkembangan kognitif, yakni membedakan bunyi, huruf, menghubungkan kata dan makna.

Selain itu, pembelajaran membaca dapat dilakukan dengan mengadopsi ilmu jiwa Gestalt sebagaimana yang dilakukan oleh Decroly (Depdikbud, 2000: 21-22). Dalam model ini, pembelajaran dimulai dari konteks, misalnya untuk membelajarkan huruf a, mula-mula anak diminta melakukan hal-hal yang ada dalam kalimat (perintah) "Ambil apel itu". Kemudian, kalimat (perintah) tersebut ditranskripsikan menjadi kartu kalimat, kartu kata, pecahan suku kata, dan huruf dan dipakai sebagai media pembelajaran pengenalan huruf a.

Berdasarkan pendekatan integratif (whole language) yang dikemukakan oleh Vigotsky, pembelajaran membaca dan menulis dilakukan secara terpadu, misalnya guru meminta anak memberi nama gambar dan guru membantu menuliskan nama gambar yang diinginkan anak. Dalam hal ini, Piaget mengemukakan empat fase perkembangan kognitif, yaitu (1) fase sensorimotor, (2) fase praoperasional, (3) fase operasional kongkret, dan (4) fase operasional formal.Selanjutnya, Bewall dan Straw (dalam Zuchdi dan Budiasih, 2001b: 51) membandingkan perkembangan kognitif Piaget dengan perkembangan bahasa sebagai berikut:

Tabel 1. Perkembangan kognitif

\begin{tabular}{|c|c|c|}
\hline $\begin{array}{l}\text { Perkiraan } \\
\text { Umur }\end{array}$ & $\begin{array}{c}\text { Fase-Fase Perkembangan } \\
\text { Kognitif Menurut Piaget }\end{array}$ & Fase-Fase Perkembangan Bahasa \\
\hline $\begin{array}{l}\text { Lahir - } \\
2 \text { tahun }\end{array}$ & $\begin{array}{l}\text { Periode Sensorimotor } \\
\text { Anak memanipulasi objek di lingkungannya } \\
\text { dan mulai membentuk konsep }\end{array}$ & $\begin{array}{l}\text { Fase Fonologis } \\
\text { Anak mulai bermain dengan bunyi- } \\
\text { bunyi bahasa, mulai mengoceh sampai } \\
\text { menyebutkan kata-kata sederhana }\end{array}$ \\
\hline $\begin{array}{l}2-7 \\
\text { tahun }\end{array}$ & $\begin{array}{l}\text { Periode Praoperasional } \\
\text { Anak memahami pikiran simbolik, tetapi } \\
\text { belum dapat berpikir logis }\end{array}$ & $\begin{array}{l}\text { Fase Sintaktik } \\
\text { Anak menunjukkan kesadaran gramatis; } \\
\text { berbicara menggunakan kalimat }\end{array}$ \\
\hline $\begin{array}{l}7-11 \\
\text { Tahun }\end{array}$ & $\begin{array}{l}\text { Periode Operasional } \\
\text { Anak dapat berpikir logis mengenai } \\
\text { benda-benda kongkret }\end{array}$ & $\begin{array}{l}\text { Fase Semantik } \\
\text { Anak dapat membedakan kata } \\
\text { sebagai simbol dan konsep yang } \\
\text { terkandung dalam kata }\end{array}$ \\
\hline
\end{tabular}

Hal yang sangat terkait dengan upaya untuk mengadopsi berbagai teori tersebut dalam rangka meningkatkan kualitas pembelajaran Membaca dan Menulis Permulaan adalah upaya 
perancangan atau pemilihan media pembelajaran. Media adalah alat bantu pengajaran dalam kegiatan belajar mengajar yang digunakan untuk menyampaikan pesan atau informasi. Media digunakan dalam kegiatan pembelajaran karena memiliki kemampuan untuk (1) menyajikan peristiwa yang kompleks dan rumit menjadi lebih sistematik dan sederhana, (2) meningkatkan daya tarik dan perhatian pembelajar, dan (3) meningkatkan sistematika pembelajaran.

Sebelum dilakukan ujicoba Media Kata Bergambar di lapangan, peneliti menyusun prototipe Media Kata Bergambar. Prototipe Media Kata Bergambar dibuat dengan bermacam ukuran dan berbagai variasi gambar. Ada beberapa perangkat prototipe Media Kata Bergambar yang memuat kata-kata yang berawal huruf dari a sampai dengan $\mathbf{z}$ dengan berbagai variasi gambar. Gambar-gambar yang dibuat divariasikan dari segi bentuk konkret gambar sesuai dengan variasi katanya, misalnya untuk huruf a digunakan kata anggur atau apel dengan memvariasikan gambar anggur dan apel. Dari hasil ujicoba Media Kata Bergambar ditemukan bahwa siswa SD kelas 1 pada pertengahan semester 1 ternyata sudah bisa membaca kata, bahkan sudah membaca kalimat.

Namun, sebagai media alternatif Media Kata Bergambar dapat dirancang sesuai dengan kebutuhan dan kemampuan siswa karena di samping sebagai media pembelajaran membaca dan menulis pada tingkat yang paling awal. Media Kata Bergambar juga dapat dipakai sebagai media untuk menguji kemampuan membaca dan menulis siswa. Misalnya, melalui pendekatan terpadu antara kemampuan berlari, keterampilan bergerak cepat, dan membaca atau menulis dengan cepat, guru dapat menguji kemampuan membaca dan menulis siswa dengan cara menyuruh siswa beradu kecepatan untuk mencari Media Kata Bergambar yang sesuai dengan huruf awal atau kata-kata yang disebutkan guru. Dalam hal ini, Media Kata Bergambar tidak difungsikan untuk media pembelajaran yang disampaikan guru di depan kelas, tetapi dapat dipakai sebagai media permainan untuk memberikan nuansa ceria dan kegembiraan dalam belajar.

Sebagai media pembelajaran yang penting digunakan di depan kelas oleh guru, Media Kata Bergambar ini sangat cocok dipakai sebagai media pembelajaran membaca dan menulis permulaan di tingkat TK maupun di kelas rendah SD. Dari pelaksanaan ujicoba, peneliti memperoleh bahan untuk mengembangkan lebih lanjut Media Kata Bergambar sebagaimana yang diharapkan, yakni yang tidak memberikan nuansa formal dan tidak menjemukan bagi anak, memberikan kesempatan kepada anak untuk mengembangkan daya asosiasinya antara gambar, huruf awal kata, dan kata. Ketika diberikan Media Kata Bergambar ini, kemungkinan mula-mula anak-anak yang belum bisa membaca, dan mengasosiakan gambar dan tulisannya secara tidak tepat, misalnya dengan penyebutan dengan menggunakan bahasa Jawa, seperti bebek untuk tulisan itik. Namun setelah dibetulkan oleh guru, mereka bisa menyebutkan tulisan yang ada di bawah gambar dengan benar.

Karakteristik dan spesifikasi prototipe Media Kata Bergambar yang telah ditentukan sebelum diujicobakan dan dikembangkan dalam penelitian ini, ternyata perlu mendapatkan pembenahan-pembenahan dan modifikasi-modifikasi tertentu agar MKB ini dapat dipakai sebagai media pembelajaran yang dapat dipakai oleh guru di depan kelas, menarik, dan lebih efektif.

Adapun karakteristik dan spesifikasi Media Kata Bergambar yang telah dikembangkan melalui penelitian ini adalah:

1. Wujud

a. Kartu atau buku (dari kumpulan kartu yang dijilid) yang setiap lembarnya terdiri atas gambar dan kata yang mengacu pada gambar tersebut. 
b. Dapat dibawa dan ditunjukkan di depan kelas kepada siswa, dapat ditempel di papan planel (dengan ditempeli perekat baju), dapat digantung di kayu panjang atau di dinding (dengan dilubangi bagian atasnya), maupun dibuat semacam album kartu kata.

2. Ukuran

a. Untuk penggunaan sebagai media pembelajaran di depan kelas digunakan kartu berukuran $20 \mathrm{~cm}$ x $30 \mathrm{~cm}$ dan $32 \mathrm{~cm}$ x $44 \mathrm{~cm}$, atau ukuran-ukuran yang lebih besar.

b. Untuk ditempel di papan planel, sebagai media permainan, dapat lebih diperkecil hingga kurang lebih $13 \mathrm{~cm}$ x $20 \mathrm{~cm}$ atau lebih kecil lagi.

3. Bentuk Tulisan

a. Berukuran besar sehingga dapat terbaca oleh siswa yang duduk paling belakang.

b. Ukuran hurufnya perlu disesuaikan dengan ukuran kartu yang digunakan.

c. Untuk kartu yang berukuran $20 \mathrm{~cm}$ x $30 \mathrm{~cm}$, huruf yang digunakan berukuran lebar 2$3 \mathrm{~cm}$, sedangkan panjangnya berukuran $3-4 \mathrm{~cm}$ (atau berukuran 72 pada pengetikan dengan komputer).

d. Untuk kartu yang berukuran $32 \mathrm{~cm} \mathrm{x} 44 \mathrm{~cm}$, huruf yang digunakan berukuran lebar 2$4 \mathrm{~cm}$, sedangkan panjangnya berukuran $4-5 \mathrm{~cm}$.

e. Menggunakan bentuk huruf cetak.

f. Tidak mempergunakan huruf kapital walaupun di awal kata.

g. Huruf pada awal kata dibuat mencolok atau menonjol dibandingkan dengan hurufhuruf berikutnya, baik dengan pemberian warna yang mencolok maupun dalam bentuk lebih besar dan tebal.

h. Posisi tulisan diletakkan di bawah gambar.

i. Tulisan yang digunakan menunjukkan contoh kata-kata yang dibakukan dalam bahasa Indonesia, bukan dari bahasa daerah.

j. Tulisan atau huruf hendaknya dibuat dengan warna-warna yang cerah namun tetap jelas.

4. Gambar

a. Merupakan gambar konkret yang diacu oleh kata yang tertulis di bawah gambar.

b. Gambar mengacu pada benda.

Media Kata Bergambar yang dikembangkan dalam bentuk kartu, didasarkan pada teori sintesa yang dikemukakan Montessori yang memberikan pengertian bahwa suatu unsur (misalnya unsur huruf) akan bermakna jika unsur tersebut berhubungan (berasosiasi) dengan unsur lain sehingga membentuk suatu arti. Terapan dari teori yang dikemukakan Montessori ini dalam pembelajaran adalah memperkenalkan huruf a disertai dengan gambar ayam, angsa, atau apel.

Bentuk Media Kata Bergambar ini diharapkan dapat menimbulkan daya asosiasi pada anak sehingga anak dapat menemukan sendiri kaidah-kaidah dalam membaca dan menulis melalui daya asosiasinya. Media Kata Bergambar ini diharapkan juga dapat memenuhi kebutuhan media pembelajaran berdasarkan metode SAS (dalam hal ini metode SAS pada tahap membaca tanpa buku) sebagai upaya untuk memberikan alternatif media pembelajaran Membaca dan Menulis Permulaan. Media Kata Bergambar ini juga diharapkan dapat meminimalkan penggunaan metode mengeja yang mungkin masih mendominasi sistem pembelajaran Membaca dan Menulis Permulaan di SD, karena sebagian guru masih tetap menganggap bahwa metode mengeja merupakan metode paling efektif dipakai untuk pembelajaran Membaca dan Menulis Permulaan karena siswa cepat bisa membaca.

Media Kata Bergambar yang dikembangkan dalam bentuk kartu, didasarkan pada teori sintesa yang dikemukakan Montessori yang memberikan pengertian bahwa suatu unsur (misalnya unsur huruf) akan bermakna jika unsur tersebut berhubungan (berasosiasi) dengan unsur lain sehingga membentuk suatu arti. Terapan dari teori yang dikemukakan Montessori 
ini dalam pembelajaran adalah memperkenalkan huruf a disertai dengan gambar ayam, angsa, atau apel.

Bentuk Media Kata Bergambar ini diharapkan dapat menimbulkan daya asosiasi pada anak sehingga anak dapat menemukan sendiri kaidah-kaidah dalam membaca dan menulis melalui daya asosiasinya. Media Kata Bergambar ini diharapkan juga dapat memenuhi kebutuhan media pembelajaran berdasarkan metode SAS (dalam hal ini metode SAS pada tahap membaca tanpa buku) sebagai upaya untuk memberikan alternatif media pembelajaran Membaca dan Menulis Permulaan. Media Kata Bergambar ini juga diharapkan dapat meminimalkan penggunaan metode mengeja yang mungkin masih mendominasi sistem pembelajaran Membaca dan Menulis Permulaan di SD, karena sebagian guru masih tetap menganggap bahwa metode mengeja merupakan metode paling efektif dipakai untuk pembelajaran Membaca dan Menulis Permulaan karena siswa cepat bisa membaca.

Dalam hal ini, guru tidak menyadari efek lain dari proses pembelajaran yang sifatnya instan. Memang, dipandang dari sisi cepatnya dipahami anak, metode mengeja lebih cepat membuat anak dapat membaca dan menulis. Namun mereka tidak menyadari efek buruknya bagi kemampuan dan keterampilan anak dalam membaca lanjut yang dimulai pada saat anak menginjak kelas $3 \mathrm{SD}$.

Efek buruk tersebut antara lain adalah (1) dalam perkembangan kognitif anak ketika membaca, mereka sudah terbiasa dengan merangkaikan huruf demi huruf sebagaimana ketika mereka mengeja sehingga pemikiran mereka sangat terbatas pada aspek struktural dan nanti sangat menghambat keterampilan membaca lanjut dan kecepatan membacanya; (2) anak yang sudah terbiasa mengeja sejak awal mereka bisa membaca maka kebiasaan tersebut akan sulit mereka hilangkan ketika mereka berada di kelas tinggi di kelas 3 atau 4, bahkan sampai di kelas 6; (3) kebiasaan mengeja juga akan mempengaruhi gerakan-gerakan fisik anak ketika membaca, misalnya membaca dalam hati namun tetap menggerak-gerakkan mulutnya sehingga akan dapat mengganggu kecepatannya membaca; dan (4) Kebiasaan membaca dengan mengeja akan memperlambat kemampuan dan keterampilan anak dalam membaca cepat sehingga akan mempengaruhi kemampuan anak untuk memahami materimateri pelajaran lain yang memerlukan keterampilan membaca dengan baik, seperti pelajaran IPA, IPS, PPKN, dan sebagainya.

Bentuk pengenalan huruf semacam ini memang memerlukan proses yang agak lama dibandingkan dengan metode mengeja. Dari penelitian yang dilakukan dapat diperoleh simpulan bahwa Media Kata Bergambar sebaiknya diberikan sejak anak berada di TK sebelum dia memasuki jenjang pendidikan SD. Ketika di TK, guru dapat memberikan berbagai variasi Media Kata Bergambar untuk memunculkan daya asosiasi pada anak. Misalnya, guru memiliki seperangkat Media Kata Bergambar untuk mengenalkan huruf a pada anak berupa Media Kata Bergambar yang menggunakan kata apel, anggur, ayam, dan sejenisnya. Maksudnya, guru tidak hanya mengenalkan satu Media Kata Bergambar untuk satu huruf a, misalnya hanya Media Kata Bergambar dengan kata apel.

Pengenalan huruf semacam ini tidak menyalahi tahap perkembangan anak pada saat itu karena tidak ada unsure pemaksaan penguasaan secara struktural terhadap penguasaan huruf. Jika anak sudah mendapatkannya di TK, maka dia akan lebih mudah menemukan konsep gramatisnya ketika di kelas 1 SD. Namun, jika penggunaan Media Kata Bergambar ini baru dimulai di kelas 1 SD maka guru akan menganggap bahwa metode SAS semacam ini tidak efektif karena pembelajarannya terlalu lama, membutuhkan energi yang cukup besar bagi guru, membutuhkan modal besar, namun anak tidak bisa menguasai kaidahnya secara cepat. Dengan demikian, guru akan mengambil jalan pintas dengan tetap membelajarkan Membaca dan Menulis Permulaan dengan menggunakan metode mengeja. Kata-kata yang digunakan 
dalam Media Kata Bergambar untuk mengenalkan huruf-huruf tertentu kepada anak juga perlu mempertimbangkan kosakata yang dibakukan dalam BI.

Dengan demikian, di samping dipergunakan untuk mengenalkan huruf-huruf tertentu kepada siswa, Media Kata Bergambar juga dapat digunakan untuk mengenalkan kosakata-kosakata dalam BI. Untuk itu, dalam Media Kata Bergambar diupayakan untuk tidak menggunakan kata-kata dari bahasa daerah (yang bukan diadopsi menjadi bahasa Indonesia) atau kata-kata yang dipergunakan oleh kelompok tertentu dalam bahasa-bahasa slang. Contohnya, gambar itik dipakai untuk mengenalkan huruf $\mathbf{i}$ dengan menggunakan tulisan kata itik di bawah gambar bukannya untuk mengenalkan huruf $\mathbf{b}$ dengan menggunakan kata bebek.

\section{Simpulan dan Saran}

\section{Simpulan}

Dari hasil penelitian dapat dikembangkan seperangkat Media Kata Bergambar yang dapat dipergunakan sebagai media alternatif dalam pembelajaran Membaca dan Menulis Permulaan di SD selain media lain yang dapat digunakan, di antaranya adalah metode syair dan lagu, metode membaca puisi, membacakan dongeng, dramatisasi, permainan boneka, dan sebagainya. Media Kata Bergambar yang dikembangkan dalam penelitian ini memiliki karakteristik dan spesifikasi tertentu yang sangat bermanfaat tidak saja untuk menunjang kemampuan membaca dan menulis anak pada tahap yang paling awal, namun juga menunjang keterampilan membaca dan menulis anak pada tahap lanjut.

Selain itu dari hasil penelitian yang saya lakukan pada kelas 1 SDN 04 pagi proses pelaksanaan membaca dan menulis permulaan dilaksanakan sesuai dengan tujuan pengajaran, media pengajaran dan evaluasi pengajaran. Dengan demikan hasil yang di peroleh sesuai dengan tujuan yang diharapkan. Usaha guru dalam meningkatkan kegiatan membaca dan menulis permulaan di kelas 1 SDN 04 pagi sudah baik, terutama didalam kegiatan membimbing murid membaca dan menulis huruf, suku kata, kata, dan kalimat

\section{Saran}

Berdasarkan simpulan penelitian ini, dapat disampaikan saran sebagai berikut bagi para dosen pengampu Matakuliah Pendidikan Bahasa dan Sastra Indonesia di Kelas Rendah di PGSD dan para guru SD, perlu memperhatikan efektivitas Media Kata Bergambar ini sebagai salah satu media alternatif dalam pembelajaran Membaca dan Menulis Permulaan. Beberapa waktu yang lalu pernah di-drop media semacam Media Kata Bergambar ini, namun tidak bertahan lama karena rusak. Untuk itu, perlu dikembangkan Media Kata Bergambar yang dapat lebih awet digunakan, misalnya dengan menggunakan bahan karton tebal atau lempengan kayu.

\section{Daftar Pustaka}

Arief, Sadiman, dkk. (2002). Media Pendidikan. Jakarta: Raja Grafindo Persada.

Borg, S (2003). The Role of Research in Teacher Education (pp 41-48), whitstable. Kent: IATEFL.

Clay, M. (2000). Educatinal Psychology in the Clasroom (6 edition). New York: Oxford University Press.

Combs, Martha. (1996). Development Competence Readers: A Praktical Guide for Teachers. New York: Longman.

Degeng, I, N. S. (2003). Teori Pembelajaran 2: Terapan. Malang: Program Magister Manajemen Pendidikan. Universitas Terbuka. 
Depdikbud. (2000). Permainan Membaca dan Menulis di Taman Kanak-Kanak. Jakarta: Depdikbud.

Gunarsa, S. D. (2008). Psikologi Anak dan Remaja. Jakarta: PT. Bpk Gunung Mulia.

Hamdani. (2005). Manfaat Media Pembelajaran. Jakarta: Pustaka Cipta.

Heinich, R, et.al. (2002). Instructional Media and Technologies for Learning. New Jersy: Merrill Prentice Hall.

Hurlock, Elizabeth. B. (2006). Psikologi Perkembangan. Jakarta: Erlangga.

Mudiono, Alif. (2000). Kemampuan Guru dalam Pembelajaran Baca Tulis Permulaan di SD dalam Jurnal Ilmu Pendidikan: Jurnal Filsafat, Teori dan Praktik Kependidikan. Malang: FIP UM.

Nisrina, Siti. (2000). Pembelajaran Membaca Permulaan Melalui Permainan Bahasa di Kelas 1 SD. Tesis. Malang.

Suyatno, Slamet. (2005). Dasar-dasar Pendidikan Anak Usia Dini. Yogyakarta: Hikayat Publishing

Wright, Andrew, David Betteridge, and Michael Buckby. (2006). Games for Language Learning $3 r d E d$, UK: Cambridge University Press.

Zuchdi, Damiyanti dan Budiasih. (2001). Pendidikan Bahasa dan Sastra Indonesia di Kelas Rendah. Jakarta: Depdikbud. 